\title{
Taking up the watch
}

\author{
Peter J. Strouse
}

Received: 12 November 2012 / Accepted: 12 November 2012 /Published online: 30 November 2012

(C) Springer-Verlag Berlin Heidelberg 2012

From the journal's inception in 1973, Walter Berdon served as one of six founding editorial secretaries of Pediatric Radiology. He was a managing editor from 1985 to 2002. The journal served as the official organ of the Society for Pediatric Radiology. The society and the journal were both small. The journal filled the need for a publication focused on pediatric radiology. Early publications focused on radiography, fluoroscopy and beginning sonography. CT and MRI were years away. Those of us blessed with modern technology can only imagine the challenges of producing the journal in an era before computers, digital photography, e-mail, faxes and numerous other technologies. Nonetheless, Dr. Berdon's office churned out a new issue every other month.

For the last 18 years, Dr. Tom Slovis has served as an editor of Pediatric Radiology. For 8 years, Tom served as an assistant editor under Dr. Berdon. For the last 10 years, Tom has served as the Editor for the Americas, working hand in hand with his European co-editors, first Steve Chapman and more recently Guy Sebag. Early in Tom's tenure, the manuscript submission and review process for the journal was migrated to online, but not without trepidation. Advances in technology have accelerated the submission and review process. E-mail and fax service have rendered communication very quick. The world is smaller than it used to be. The journal is global.

In the last 10 years, under Tom's stewardship, the content and quality of the journal have continually improved. Review articles and mini-symposia have been

P. J. Strouse $(\bowtie)$

Department of Radiology, Section of Pediatric Radiology,

University of Michigan Health System,

C.S. Mott Children's Hospital, 3-231,

1540 E. Hospital Drive,

Ann Arbor, MI 48109-4252, USA

e-mail: pstrouse@umich.edu introduced, providing immense value to our readership. Case reports, long a staple of the journal, remain but only those that truly teach us something new ("are prescient"). Original articles must achieve a high standard to warrant publication.

Tom Slovis demands high standards and, under his watch, the journal has achieved this. Manuscripts must be well written. Content must benefit the readers. Science must be good. Illustrations must tell the story and must "jump out at you." During his tenure Tom has reviewed nearly every image that has appeared in the journal and, with his photography assistant, he has cropped, adjusted and relabeled countless images for optimal clarity. Tom has consistently insisted that Springer, our publishing partner, maintain similar high standards regarding layouts, copy editing and picture quality in print. The result is a high-quality journal.

Tom's leadership style is simple. Work hard. Do what is right. Do it well. Encourage others to follow. Recognize achievement and excellence. Value leadership. Value visionary thought. Be honest. Be reliable. Be efficient. Be passionate.

Tom Slovis is passionate about the care of children. Everything that he has done as a physician, researcher, author and editor has that as its focus. In editorials, Tom has preached the need to provide value-added service and to be the child's doctor, always acting in the best interest of the child. As Chair of Radiology at Children's Hospital of Michigan he has practiced what he preaches. Tom is passionate about minimizing radiation dose in children. He has been at the forefront of our campaign to manage radiation dose in pediatric radiology. Tom was a key player in planning the first ALARA meeting on CT. Tom is passionate about properly diagnosing child abuse, differentiating it from other processes, and making the correct diagnosis for the good of the child. Like all of us, he is saddened by the 
child abuse contrarians who needlessly and recklessly challenge our ability to diagnose and protect our world's greatest resource.

Tom will not retire, nor will he willfully fade into the sunset. He will continue to contribute actively to the journal as an editor emeritus, functioning as an adviser to the editorial team, hopefully contributing an occasional commentary, and serving as a reviewer from time to time. Tom has many other passions to keep him busy - photography, travel, Telluride, New York Giants football, Detroit Tigers baseball, University of Michigan football and basketball
(Go Blue!), watching his grandsons play hockey, innumerable friends, and, most of all, his family.

Tom leaves very big shoes to fill. To some extent, however, Tom has made it easy. He has assembled a great team of contributors and built an infrastructure for sustained excellence. The journal is a point of pride for our specialty. Tom has walked the walk and talked the talk. He has been a great mentor and showed us the proper way to serve as editor. It is with great humility that I become editor of this great journal. It is truly an honor and privilege to follow my good friend Tom Slovis. 